\title{
Embryo transfer and related technologies in sheep reproduction
}

\author{
Pasqualino Loia*, Grazyna Ptak ${ }^{\mathrm{b}}$, Maria Dattena ${ }^{\mathrm{a}}$, Sergio Ledda ${ }^{\mathrm{c}}$, \\ Salvatore Naitana ${ }^{\mathrm{c}}$, Pietro Cappai ${ }^{\mathrm{a}}$ \\ a Istituto Zootecnico e Caseario, 07040 Olmedo, Sassari, Italy \\ b Department of Animal Reproduction, University of Agriculture, 30059, Krakow, Poland \\ ${ }^{\mathrm{c}}$ Dipartimento di Biologia Animale, Università di Sassari, Italy
}

(Received 31 July 1998; accepted 13 October 1998)

\begin{abstract}
This paper reviews the status of embryo transfer and the major technologies applied to preimplantation of embryos in sheep. Embryo production from superovulated ewes is hindered by an unpredictable response to hormonal treatment. Progress in this area should be expected by an appropriated control of follicular development with gonadotropin-releasing hormone $(\mathrm{GnRH})$ agonist or antagonist prior to gonadotrophin administration. Simple protocols for the cryopreservation of sheep embryos by vitrification are already available and the development of frozen-thawed blastocysts to term is close to the fresh ones. Further research is required to identify factors able to promote the maturation in vitro of oocytes, namely those obtained from prepubertal animals. Semen and embryo sexing procedures are available in cattle although much less attention was paid to their application to sheep. Among all the reproductive technologies, cloning with embryonic and foetal cells has progressed dramatically in sheep and nuclear transfer has been used to produce transgenic animals as an alternative to pronuclear injection. The production of the first lamb cloned from a somatic cell opened new opportunities in animal breeding as well as exciting lines of basic research. The overall conclusions are that, apart from superovulation, the application of in vitro technologies is likely to evolve rapidly and once applied, a great impact on traditional and new animal productions should be expected. However, a better understanding of the changes in gene expression, induced in embryos by different in vitro manipulation procedures, is necessary to prevent abnormal foetal development. (C) Inra Elsevier, Paris.
\end{abstract}

superovulation / in vitro maturation / embryo freezing / nuclear transfer / transgenesis / sheep

Résumé - Transfert d'embryons et techniques associées en reproduction ovine. Cette revue traite du transfert d'embryons et des principales biotechnologies appliquées à l'embryon ovin. La production d'embryons, après superovulation, est limitée par la réponse non reproductible au traitement hormonal. Un progrès pourrait venir d'un contrôle approprié du développement folliculaire

\footnotetext{
* Correspondence and reprints

E-mail: izcscrip@tin.it
} 
avec un agoniste ou antagoniste de GnRH appliqué avant le traitement gonadotrope. Des protocoles simples pour la congélation d'embryons ovins par vitrification sont disponibles et, après décongélation, le développement à terme de blastocystes congelés est proche de celui des embryons frais. De nouvelles recherches seront nécessaires pour identifier les facteurs capables de stimuler la maturation in vitro des ovocytes, en particulier ceux d'animaux prépubères. Le sexage des spermatozoïdes et des embryons est possible chez les bovins, mais peu appliqué chez les ovins. De toutes les techniques de reproduction, c'est celle du clonage à partir de cellules embryonnaires ou fœtales qui a le plus progressé ; le transfert nucléaire a été utilisé pour produire des animaux transgéniques, comme alternative à l'injection dans les pronoyaux. La production du premier agneau cloné à partir d'une cellule somatique a ouvert de nouvelles perspectives en élevage et en recherche fondamentale. En conclusion, excepté dans le domaine de la superovulation, les biotechnologies vont évoluer rapidement ; leur application aura certainement un grand impact sur les méthodes traditionnelles et nouvelles de production. Cependant, une meilleure connaissance des effets sur l'expression de gènes embryonnaires induits par les manipulations in vitro serait nécessaire pour éviter un développement fœtal anormal. 도 Inra/Elsevier, Paris.

\section{superovulation / maturation in vitro / congélation d'embryons / transfert nucléaire / homogenèse / mouton}

\section{INTRODUCTION}

Nearly all the technologies related to embryo production and manipulation in domestic ruminants, from artificially controlled breeding to the production of Dolly, the first cloned mammal, have been developed in sheep, before being transferred to its more economically important counterpart, the bovine.

The aim of this work is to review the technologies used in sheep reproduction with a particular emphasis on the limits and the perspectives for improvement. Secondly, the potential value of these new technologies in sheep breeding and reproduction is described and finally, already known and new aspects of abnormal foetal development associated with in vitro manipulation are discussed.

\section{SUPEROVULATION}

Small-scale studies in sheep embryo transfer reported 40 years ago [7] established the basic techniques for surgical recovery of embryos (reviewed by Moore [68]). The Australian experiments leading to the artificial control of oestrus [90] followed by the identification and purification of gonadotrophins, provided the basis for the development of suitable protocols for sheep superovulation.

An enormous amount of literature concerning superovulation in sheep has been produced and from its analysis it is evident that an accurate control of ovulation has never been achieved. Embryo yield after superovulation is dependent upon many factors that can be grouped as follows.

1) Factors inherently variable and difficult to modify (breed, season, management). It is easy to understand that very little improvement can be expected from factors like breed and consequently flock management [21] as well as nutrition [61]. Breeding dairy Sarda ewes in Sardinia imposes a different management from that required for breeding Merino ewes in New Zealand or Scottish Blackface in Scotland; moreover, the ovarian response of Sarda ewes to the same commercial gonadotrophin preparation will always be different from that of Merino ewes [60, 72]. However, a major effort has been made by reproductive biologists in the past to fit suitable superovula- 
tion protocols into a large number of domestic breeds under a broad environmental range (see [45]).

2) Factors susceptible on improvement (gonadotrophin, knowledge of ovarian physiology). Pregnant mare serum gonadotrophin (PMSG) [6], pituitary extracts of different origin $[28,69,96]$ and human menopausal gonadotrophin [92] are commonly used for superovulation in sheep. The biological properties of the gonadotrophins used for superovulation have been described in detail elsewhere [13]; for review see [45]) Exogenous gonadotrophin interplay with the somatic and germinal compartments of the follicle leading to the ovulation of a number of oocytes larger than normal. However, there is evidence that their action is modulated at the ovarian level, thereby making the answer unpredictable. Furthermore, additional negative effects can occur before ovulation, as a consequence of inadequate oocyte maturation [67] or later, during early embryonic development as a result of unbalanced hormonal profiles $[3,51]$. Several strategies have been suggested for optimizing the yield of transferable embryos from superovulated donors: the administration of anti-PMSG antibodies [12], pituitary follicle-stimulating hormone (FSH) instead of PMSG [66], association of these two gonadotrophins [91], single versus multiple injections [30, 64], or inclusion of $\mathrm{GnRH}$ or growth hormone in the treatments [36, $111]$.

However, the well-known side-effects of the superovulatory treatment such as unovulated follicles, low fertilization and recovery rates (reviewed by Naitana et al. [72]) were left largely unsolved. Undoubtedly, the balance between FSH and luteinizing hormone (LH) components or the purity of the gonadotrophin preparation play an important role [24]; the availability of recombinant FSH [59] should in theory reduce the negative side effects linked to the purity of the commercial preparation. Nevertheless, our opinion is that no obvious improvements should be expected even from the adoption of highly purified hormones until systems for controlling follicular recruitment and selection are available.

More recently, a detailed understanding of the processes involved in the growth and differentiation of the ovulatory follicles [33] has been achieved and many strategies have been suggested to control the follicular wave emergence in cattle [15]. Unfortunately, analogous work has not been repeated in sheep because there is a more commercial interest for multiple ovulation and embryo transfer (MOET) in cattle and intrinsic differences between species in the process of follicular selection [33].

Progress made by reproductive endocrinologists dealing with follicular dynamics provided the necessary tools for a radical change in superovulation treatments. Chronic treatment with GnRH agonist inhibits the gonadotrophin-dependent follicular growth by downregulating $\mathrm{LH}$ secretion from the pituitary [17]. This observation suggests that a treatment with GnRH agonist followed by the administration of exogenous gonadotrophin, may in theory produce a uniform cohort of follicles available for ovulation. This theory has yet to be proven in sheep, but encouraging results in a small scale experiment were obtained, where the number of transferable embryos was increased in ewes treated with GnRH agonist [16].

The downregulation of follicular development with long-term treatment of GnRH analogues or antagonists (Gong, pers. comm.) prior to the administration of highly purified gonadotrophin appears to be a very promising line of research for the improvement of superovulation.

\section{INSEMINATION OF THE DONORS}

Regardless of the stimulation regimen used, reduced fertilization rates after natural 
mating are a common occurrence in superovulated ewes, especially in those females exceeding ten ovulations (reviewed by Gordon [45]). This problem has been overcome by Trounson and Moore [109] with the surgical deposition of semen directly into the uterine horns; the following introduction of laparoscopic intrauterine insemination completely resolved this inconvenience [89]. Usually, a single insemination performed around $48-50 \mathrm{~h}$ after sponge removal does not interfere with ovum pick from the fimbria and gives satisfactory fertilization and recovery rates [94].

\section{EMBRYO RECOVERY AND TRANSFER}

Sheep embryos are usually surgically recovered using the method suggested by Hunter and co-workers [50]; briefly, the uterus and oviducts are exposed to a midventral laparotomy and the reproductive tract is flushed with different shaped catheters with sterile medium. A much smaller incision was required for the partial exposure of the uterine horns in the technique suggested by Tervit and Havik [101]. Laparoscopic techniques were later introduced for embryo recovery to reduce the extent of surgical intrusion [63]. While this approach did allow repeated recoveries from the same animal, the average yield from a single flushing was lower than surgical collection [95]. Although some success has been described for cervical collection of embryos [10], more work is necessary to make it a reliable option in sheep. The embryos are usually recovered at the morula-blastocyst stage, 6-7 days after the induced oestrus, evaluated under a dissecting microscope before being frozen or immediately transferred, either by laparotomy or laparoscopy [62], into suitable synchronous recipients. The development to term of fresh embryos is around $70 \%$, with differences depending on breeds (reviewed by Gordon [45]).

\section{REPEATED SUPEROVULATION}

Once a suitable superovulation protocol is established, the next step is to verify the responsiveness of the same donor to repeated treatments. Work from Moore and Shelton [69] in Australia demonstrated that multiple superovulation can be induced in sheep at a 1-year interval without a significant reduction in the ovarian response. Torres and Sevellec [108] later came to the same conclusion. Whether immunological responses induced by the gonadotrophins used for superovulation can reduce the ovarian response still remains an open question. However, the side-effects of repeated treatment with gonadotrophins [34] are not the major factor limiting multiple superovulation in sheep. Adhesions caused by the repeated laparotomic collection and protrusion of the endometrium at the puncture site in the laparoscopic recovery, may reduce the number of flushings obtainable from one donor [76].

\section{EMBRYO FREEZING}

Protocols for freezing sheep embryos have been available since the 1970s, after the first lamb was born following a transfer of a frozen-thawed embryo [120]. In the original protocol, the embryos were incubated in appropriated concentration of permeating cryoprotectors, cooled $3-4{ }^{\circ} \mathrm{C}$ below the freezing point, then ice nucleation was induced in the medium by touching the vial with a pair of pre-cooled forceps. The cryoprotectant was removed step-wise after thawing and the embryo was ready for transfer. Once the procedure was established, research continued to increase embryo survival through the adoption of low toxicity cryoprotectants such as ethylene glycol [102] and particularly after the incorporation of a non-permeating osmotic buffer, sucrose (reviewed by Rall [86]) into the freezing medium, which allows direct transfer after thawing as first suggested by 
Heyman and co-workers [49]. A further innovation in the cryopreservation of mammalian embryos was later suggested by Rall and Fahy [87]. In this experiment, embryos were cooled very rapidly at thousands of degrees per minute in a high concentration of cryoprotectants which formed a glass structure without the formation of ice crystals. This procedure, called vitrification, has been adapted for many species including sheep [1] and the results in terms of survival rate and lambs born are continuously progressing $([1,99]$, reviewed by Niemann [78]). Furthermore, the vitrification protocols in sheep are becoming increasingly well defined, thus eliminating the expensive programmable cryogenic units in the field [75]. Studies from Naitana et al. [73] indicated that the synchronization between recipient and embryos is very critical when vitrifiedthawed embryos are transferred.

\section{ALTERNATIVE ROUTES FOR SUPEROVULATION}

\subsection{In vitro maturation}

In vitro maturation (IVM) usually involves selection of non-atretic enclosed cumulus, fully grown oocytes and maturation in either droplets or Petri dishes for approximately $24 \mathrm{~h}$ at $39^{\circ} \mathrm{C}$. Meiotic maturation occurs spontaneously after removal of the oocyte from the follicle [37], but the addition of gonadotrophins in vitro increases the number of oocytes that progress to metaphase II (MII), although it does not increase their developmental potential [38]. Maturation is usually performed in tissue culture medium 199, as pioneered by Moor and collaborators $[65,98]$. Foetal bovine serum is the commonest supplement, but recently, the addition of growth factors, in particular epidermal growth factor (EGF), insulin-like growth factor I (IGF-I) and transforming growth factors- $\alpha$ (TGF- $\alpha$ ), has been shown to stimulate oocyte maturation and to reduce the requirement for gonadotrophins during maturation $[42,46$, 54]. Recent experiments presented the relationship between glutathione and developmental competence following in vitro maturation of bovine oocytes [31]. Two years later the use of cysteamine, which increases the glutathione level in oocytes, was already adopted for in vitro embryo production using sheep [115] and lamb oocytes [83].

\subsection{In vitro fertilization}

In 1985, Cheng reported a high fertilization rate of sheep oocytes matured in vitro [22]. In this system, the semen was resuspended in medium containing oestrus sheep serum. This serum supplementation was also used by Crozet et al. [29] and still remains the most effective capacitating factor in sheep. Later, Pugh and co-workers [85] reported the birth of the first lambs following IVM/in vitro fertilization (IVF)/in vitro culture (IVC) of oocytes collected during non-breeding season. This study clearly demonstrated the importance of gonadotrophin priming prior to collection for subsequent developmental ability of the oocytes. In fact, in agreement with an earlier report of Cheng [22], fewer oocytes from abattoirderived ovaries were successfully fertilized after IVM/IVF than oocytes from ewes receiving low dosages of FSH prior to slaughter. We had the same experience when working with Sarda milk sheep: oocytes collected at slaughter during the non-breeding season and subjected to in vitro techniques had a very low developmental competence. The situation was reversed when treating the females with low doses of FSH (Ptak, unpublished observations). The positive FSH priming effect may be exerted through a direct stimulation of the cumulus/granulosa cells, indirectly through a stimulation of follicular growth or both [26]. 


\subsection{In vitro culture}

There are essentially two culture systems now used for blastocyst production in vitro: co-culture (or medium conditioned on cells) and defined (semi-defined). Co-culture of sheep embryos is generally performed with TCM199, usually supplemented with serum. The cells of choice are granulosa, oviduct epithelial or buffalo rat liver cells. The coculture technique was described primarily by Rexroad and Powell [88] and Gandolfi and Moor [41]. There is evidence that growth-promoting factors (peptide growth factors and/or cytokines) are responsible for supporting the development of the embryos in both co-culture and conditioned media [40]. It was also discussed that these culture methods simply reduce or remove inhibitory components, such as glucose and oxygen [11, 114].

In defined culture systems, the concentration of each component is known before the addition of embryos (unless serum is used). At present, the most commonly used system for the culture of sheep embryos is synthetic oviduct fluid medium (SOF; [103]) enriched with amino acids and bovine serum albumin (SOFaaBSA; [43]). This method yielded blastocysts with comparable cell numbers to in vivo-derived counterparts, in contrast to sheep embryos incubated with human serum which develop to blastocysts with lower cell numbers [43, 112]. Ovine embryos cultured in the presence of human serum reach the expanded blastocyst stage approximately $24 \mathrm{~h}$ earlier than their in vivo counterparts [112]. This premature blastulation and other abnormalities such as fragmentation of embryos, dark appearance and reduced cell numbers were reported by the same Australian group [113] who also considered increased gestation length and some perinatal problems with lambs derived from embryos cultured with $20 \%$ of human serum. Such problems were not confirmed for lambs obtained after culture in the SOFaaBSA system [107]. Despite progress in the culture of ovine embryos, there are still some differences between in vitro- and in vivo-derived embryos. Development through the fourth cell cycle, which is associated with the major activation of the embryonic genome, is retarded during in vitro culture and the degree of compaction at the morula stage differs from the in vivoderived morula [106].

\section{OVUM PICKUP}

Snyder and Nellor [97] reported for the first time laparoscopic recovery of sheep oocytes but several years later the technology was optimized in terms of recovery rate and quality of the aspirated oocytes [104, 105]. In 1996, Tervit [100] summarized the results of two groups involved in the exploitation of ovum pickup in sheep. The first group showed a large variation among females in the production of blastocysts, with only $32-56 \%$ of donors producing at least one blastocyst [8]. In the second group the average donor produced between 2.3 and 3.2 blastocysts resulting in about 1.5 lambs born [100]. It was concluded, that the technology could be useful for producing offspring from infertile ewes but needed improvement before it could replace MOET. In our laboratory, we stimulated ewes using the Tervit protocol and recovered 14 oocytes per ewe with the use of laparotomy with an average of more than three blastocysts per donor; however, the oocyte and blastocyst yield gradually decreased per session ( 5 and 0.6 , respectively, at the fifth session) [84].

\section{PREPUBERTAL EWES}

The production of embryos from juveniles should potentially increase the rate of genetic gain through a reduction of the generation interval. In some studies reporting the developmental ability of prepubertal ewes it is observed that although the nuclear maturation occurs at a comparable rate for oocytes from both adult and prepubertal 
ewes, normal fertilization and development do not follow; this can be largely attributed to abnormal cytoplasmic maturation [56, $80,81]$. In fact, a lower metabolism of glutamine for lamb oocytes, whether matured in vivo or in vitro, and a higher incidence of polyspermic fertilization were reported [79]. However, due to the observations of different groups [4], the rate of development of lamb oocytes in vitro from blastocysts was similar to those observed for embryos derived from adult donors. Based on appropriate follicle stimulation protocols using 6-8-week-old lambs, up to ten pregnancies per donor oocyte collection session after transfer of IVF embryos is speculated [5, 35].

\section{SPLITTING}

The procedure for the multiplication of the cleavage stage of sheep embryos has been described in detail by Willadsen [116]. However, the loss of nuclear totipotency, as a result of cell differentiation in developmentally regulated embryos, is the main limit of blastomere separation. In fact, embryos are scheduled to compact and blastulate after five to six cell cycles and consequently, the cell number is proportionally reduced in manipulated embryos. In fact, the survival to term of blastocysts derived from embryos containing $1 / 2,1 / 4$ and $1 / 8$ of the blastomeres was 80,50 and $6 \%$, respectively [117]. A simpler procedure, known as embryo splitting, was later introduced to divide morula-blastocyst stage sheep embryos $[44,119]$ with no deleterious effect on embryo viability provided that the blastocyst is symmetrically divided [23]. Embryo splitting has been simplified dramatically and has been used in the commercial embryo transfer industry in sheep [110]. However, the insurmountable limit of embryo splitting is the limited number of obtainable offspring per manipulated embryo.

\section{PRESELECTION OF GEN DER BY SPERM SEPARATION AND EMBRYO SEXING}

The yield of sorted $\mathrm{X}$ and $\mathrm{Y}$ bearing sperm in cattle with fluorescence-activated cell sorter (FACS) technology has improved dramatically [52] and small scale trials of artificial insemination with selected semen have also been carried out in sheep [27]. Once again, although in theory ram semen may be FACS processed with comparable efficiency, its use in artificial insemination in sheep is limited by the high cost of the technology.

The situation does not change for embryo sexing by polymerase chain reaction (PCR). Commercial kits for field sexing cattle embryos by PCR are available at reasonable prices and probably, given the high analogy between species, most of them may be successfully used for sexing sheep embryos; however, only very limited or preliminary reports have been published [74].

\section{CLONING}

Since the first report of lambs produced by nuclear transfer [118] the sheep has always represented a central experimental model for basic and applied research. No tentative will be made in this review to describe the technique of nuclear transfer because this topic has been exhaustively treated by Heyman [47, 48]. The present discussion will be limited to sheep nuclear transfer.

The key to the right interpretation of the poor development of nuclear transfer embryos obtainable a few years ago was provided by classical hybrid cell fusion experiments [53] where a dominant effect of mitosis on the other cell cycle phases was demonstrated. The MII oocyte follows this basic rule, as was clearly demonstrated by the disorganization of the nuclear envelope and the condensation of the chromatin 
imposed to the transferred nucleus (premature chromosome condensation, PCC), regardless of its cell cycle stage. $\mathrm{PCC}$, mediated by the MPF, results in extensive damage of the chromatin when the replication machinery is on, as in the majority of blastomeres in cleavage stage embryos [18]. The nuclear envelope plays a central role in regulating the duplication of DNA [14], and its disorganization in MII cytoplast is followed by the replication of previously replicated DNA with the exception of the very few nuclei that are in G1 (reviewed by Campbell et al. [19]). From these important observations, it was concluded that the normal development of embryos reconstructed by nuclear transfer could only be obtained by fusing synchronized G1 blastomeres into MII cytoplasts or alternatively, by fusing unsynchronized blastomeres with pre-activated S phase cytoplasts [18]. While protocols for the synchronization of blastomeres are available in the mouse [82], this and other procedures are unreliable in sheep embryos (Loi, unpublished observations). Pre-activated cytoplasts increased the frequency of development to the blastocyst stage and to the term of cloned sheep embryos [57]. This procedure, however, is quite time-consuming because a two-step manipulation is required for embryo reconstruction. In subsequent work carried out in our laboratory, a high frequency of development to the blastocyst stage was obtained by transferring unsynchronized blastomeres from 16-32 cell embryos into MII enucleated oocytes activated with ionomycin and a protein kinase inhibitor, 6-dimethylaminopurine (6-DMAP) [58]. In previous work, activated mouse eggs treated with 6DMAP showed an accelerated pronuclear organization [71], thereby indicating the inhibition of kinase(s) involved in the nuclear membrane assembly and chromatin structure. Moreover, these effects occurred without any interference to DNA replication [55]. Our hypothesis was found to be correct and no structural and functional alterations were detected in the nuclei of recon- structed embryos treated with 6-DMAP. With this protocol, unsynchronized blastomeres can be safely transferred into MII without any nuclear damage. As in the universal recipient and in the Gl protocol, nuclei are exposed to reprogramming factors throughout the first cell cycle. However, the number of blastomeres composing an embryo limits the size of the obtainable clones. The establishment and maintenance in culture of permanent cell lines derived from ovine embryos could provide an unlimited number of genetically identical nuclei for nuclear transfer. Such an approach was first undertaken in sheep by Galli and co-workers [39], who transferred embryo-derived cells into enucleated oocytes. Four normal embryos were transferred and one pregnancy was established until day 45. Subsequent nuclear transfer experiments carried out at the Roslin Institute with cultured cells derived from embryos, foetuses and adult sheep overcame the established limits of reproductive biology [20] and the first lamb cloned from somatic cell was produced [122]. These insights opened new opportunities in animal breeding and also confirmed nuclear transfer as the proper tool to unravel the complex mechanism of developmental biology. This formidable achievement persuaded embryologists to focus their attention on the nuclear transfer of foetal cells [115] and therefore technological improvements should be expected in the near future.

\section{GENETIC MANIPULATION}

Direct injection of DNA into pronuclear stage embryos was used to obtain the first transgenic sheep which produced human anti-emophylic factor IX in milk [25]. Direct injection of DNA was later used for a variety of applications. The major limit of this technique is the small proportion of animals that integrate the transgene into their genome. Exogenous DNA is probably integrated by repair mechanisms at the breakage 
sites of the chromosomes induced by the injected fluid. This random integration would certainly account for the wide range of situations resulting after pronuclear injection: extensive damage incompatible with further development of the embryo, lethal mutation caused by the interruption of a key gene, silencing of the transgene and finally, in less than $1 \%$ of the animals, unpredictable expression of the transgene (reviewed by Wilmut and Clark [121]). In spite of its empirical basis, direct injection of foreign DNA has been used to create sheep expressing pharmaceutical proteins in their milk [123]. More accurate genetic modification can be introduced by gene targeting of cultured cells. This approach is based upon recombination of the introduced gene with complementary sequences of the targeted chromosome in order to insert the foreign DNA exactly in the predicted position. Homologous recombination is now routinely used for the genetic modification of mouse embryonic stem cells. Successfully modified cells are then introduced into or aggregated with normal embryos to produce chimeras; when genetically modified cells contribute to the germ line of the chimera, the new character is transmitted to the offspring. Unfortunately, stem cells have not been isolated from embryos of domestic animals until now. The production of live lambs from nuclear transfer of a cultured cell line [20] has opened the possibility to induce precise genetic changes in species other than mice. In fact, a landmark paper published later by the same group clearly demonstrated the possibility to produce transgenic lambs by transferring genetically modified nuclei into enucleated oocytes [93]. Nuclear transfer mediated transgenesis offers several advantages comparing to pronuclear injection. First, half of the animals are necessary to generate one transgenic lamb. Furthermore, no recipients are wasted for gestation of nontransgenic offspring. A common problem after pronuclear injection in the delayed integration of microinjected DNA results in mosaic animals; in contrast, transgenic ani- mals produced by nuclear transfer are entirely transgenic. Finally, nuclear transfer allows the sex of the animal to be predetermined, thus increasing the efficiency two-fold, when the sex of the transgenic animal is critical, for instance, in milk production.

\section{ABNORMAL FOETAL DEVELOPMENT}

The birth of unusually large lambs, associated with abnormal deliveries and high incidence of perinatal death, has been reported to occur after nuclear transplantation, asynchronous transfer and transfer of in vitro produced embryos, particularly in the presence of serum (reviewed by Walker et al. [113]). Apparently, an inappropriate environment where the embryo is stored for a relatively long time or an extensive manipulation, such as genome reprogramming after nuclear transfer, disturbs genes concerned with the regulation of foetal growth. Like all the laboratories dealing with the majority of embryo manipulation, we experienced all the aspects of the so-called large calf-lamb syndrome. Apparently, there is no or only very little maternal contribution to labour, probably as a consequence of the absence of hormonal signals produced by the foetal adrenal gland at the end of the pregnancy. Moreover, we have observed the occurrence of undershot lower jaws in lambs derived from in vitro produced and cloned embryos; the same phenotype was noted from Schnieke and co-workers [93] in all the lambs derived from a cell line. Interestingly, the same phenotype was described in entirely derived stem cell mouse embryos as a result of deregulation of imprinted genes during in vitro culture [32].

\section{CONCLUSION}

The domestication of sheep played a major role in the development of the civilizations in Mediterranean countries. Nowa- 
days, sheep breeding has an important impact on the economy of large regions such as Italy, France, Spain and Greece. The last two decades have dramatically changed the management of sheep breeding, mainly dairy sheep, through improved pasture, nutrition and veterinary assistance. However, despite these improvements, artificial insemination is the only reproductive technology applied in selection programmes. A large number of reviews on the impact of reproductive technologies on genetic improvement has been written so far but it is difficult to draw precise indications from them. MOET can increase genetic gain from 15 to $40 \%$ in small and up to $100 \%$ in large flocks according to some authors [77] or have negligible effects according to others [9]. All these considerations are based upon theoretical models because to our knowledge, no field trial has been undertaken to evaluate the impact of these reproductive technologies on sheep breeding strategies. However, several sheep breeds, namely in the Mediterranean basin, have evolved into dairy models closer to the cattle with modern husbandry methods including milking machines. This situation lets us perceive that reproductive technologies other than AI are going to be considered by geneticists. Among the technologies described here, some have a limited perspective for improvement, particularly the surgical or laparoscopic procedures. The principal ones, however, like superovulation and all in vitro technologies including cloning, still have a large margin for improvement. Technologies like cloning or transgenesis which are expensive and technically complex, are already employed by biotechnological companies and the production of pharmaceutical proteins from transgenic animals is very close to reaching commercial applications. Nevertheless, it is essential that factors responsible for abnormal foetal development, resulting from in vitro manipulation, are identified and removed before a largescale application of these technologies can be made.

\section{REFERENCES}

[1] Ali J., Shelton J.N., Design of vitrification solution for cryopreservation of embryos, J. Reprod. Fert. 99 (1993) 47I-477.

[2] Ali J., Shelton J.N., Successful vitrification of day 6 sheep embryos, J. Reprod. Fert. 99 (1993) 65-70.

[3] Armstrong D.T., Evans G., Factors influencing success of embryo transfer in sheep and goats, Theriogenology 19 (1983) 31-42.

[4] Armstrong D.T., Irvine B., Earl C.R., In vitro fertilization of follicular oocytes from juvenile lambs and their developmental competence in vitro and in vivo, Biol. Reprod. 50 (Suppl. 1) (1994) 189

[5] Armstrong D.T., Kotaras P.J., Earl C.R., Advances in production of embryos in vitro from juvenile and prepubertal oocytes from the calf and Jamb, Reprod. Fert. Dev. 9 (1997) 333 339.

[6] Averill R.L.W., The production of living sheep eggs, J. Agric. Sci. 50 (1958) 17-33.

17] Averill R.L.W., Rowson L.E.A., Ovum transfer in sheep, J. Endocrinol. 16 (1958) 326-336.

[8] Baldassarre H., Furnus C.C., de Matos D.G., Pessi H., In vitro production of sheep embryos using laparoscopic folliculocentesis: alternative gonadotrophin treatments for stimulation of oocyte donors, Theriogenology 45 (1996) 707-717.

[9] Barillet F., Genetic of milk production, in: Piper L. Ruvinsky A. (Eds.), The Genetics of Sheep, CAB International Wallingfard, UK, 1997, pp. 539-564.

[10] Barry D.M., van Niekerk C.H., Rust J., Vanderwalt T., Cervical embryo collection in sheep after ripening of the cervix with prostaglandin $\mathrm{E} 2$ and estradiol, Theriogenology 33 (1990) 190.

[11] Bavister B.D., Co-culture for embryo development: is it really necessary, Hum. Reprod. 7 (1992) 1339-1341

[12] Bindon B.M., Piper L.R., Induction of superovulation in sheep and cattle by injections of PMSG and ovine anti-PMSG immune serum, Theriogenology 8 (1977) 171 .

[13| Bindon B..M., Piper L.R., Cahill L.P., Driancourt M.A., O'Shea T., Genetic and hormonal factors affecting superovulation, Theriogenology 25 (1986) 53-70.

[14] Blow J.J., Laskey R.A., A role for nuclear envelope in controlling DNA replication within the cell cycle, Nature 332 (1988) 546-548.

[15] Bo G.A., Adams G.P., Pierson R.A., Mapletoft R.J., Exogenous control of follicular wave emergence in cattle, Theriogenology 43 (1995) 31-40.

116] Briois M., Belloc J.P., Brebion P., Guerin Y., Cognie $Y$., Increased embryo production in superovulated elite Lacaune ewes pre-treated with a GnRH agonist, 8th AETE Scientific Meeting., Lyon, 1992, p. 132. 
[17] Campbell B.K., Scaramuzzi R.J., Webb R., Control of antral follicle development and selection in sheep and cattle, J. Reprod. Fertil. Suppl. 49 (1995) 335-350.

[18] Campbell K.H.S., Loi P., Cappai P., Wilmut I., Improved development of ovine nuclear transfer embryos reconstructed during the presumptive $S$-phase of enucleated pre-activated oocytes, Biol. Reprod. 49 (1994) 933-942.

[19] Campbell K.H.S., Loi P., Otaegui P.J., Wilmut I., Cell cycle co-ordination in embryo cloning by nuclear transfer, Rev. Reprod. I (1996) 40-46.

[20] Campbell K.H.S., McWhir J., Ritchie W.A., Wilmut I., Sheep cloned by nuclear transfer from a cultured cell line, Nature 380 (1996) 6466.

[21] Cappai P., Cognié Y., Branca A., Use of the ram effect to induce sexual activity in Sarda ewes, in: Courot M. (Ed.), The Male in Farm Animal Production, Martinus Nijhoff Publishers, 1984, pp. 316-321.

[22] Cheng W.T.K., In vitro fertilization of farm animal oocytes, Ph.D. thesis, University of Cambridge, 1985.

[23] Chesné F., Colas G., Cognié Y., Guérin Y., Sevellec C., Lamp production using superovulation, embryo collection and transfer, Theriogenology 25 (1987) $751-757$.

[24] Chupin D., Combarnous Y., Procureur R., Antagonistic effect of LH on FSH induced superovulation in cattle, Theriogenology 21 (1984) 219

[25] Clark A.J., Bessos H., Bishop J.O., Brown P., Harris S., Lathe R., McClenaghan M., Prowse C., Simons J.P., Withelaw C.B.A., Wilmut I., Expression of human anti hemophilic Factor IX in the milk of transgenic sheep, Biol. Technol. 7 (1989) 487-492.

[26] Cognié Y., Benoit F., Poulin N., Khatir H., Driancourt M.A., Effect of follicle size and of the $\mathrm{Fec}{ }^{\mathrm{B}}$ Booroola gene on oocyte function in sheep, J. Reprod. Fert. 112 (1998) 379-386.

[27] Cran D.G., McKelvey W.A.C., King M.E., Dolman D.F., McEvoy T.G., Broadbent P.J., Robinson J.J., Production of lambs by low dose intrauterine insemination with flow cytometrically sorted and unsorted semen, Theriogenology 47 (1997) 266.

[28] Crosby T.F., Superovulation in sheep: the effects of pFSH type and ewe breed, Theriogenology 39 (1993) 205.

[29] Crozet N., Huneau D., Desmedt V., Théron M.-C., Szollosi D., Torres S., Sevellec C., In vitro fertilization with normal development in the sheep, Gam. Res. 16 (1987) 159-170.

[30] Dattena M., Vespignani S., Branca A., Gallus M., Ledda S., Naitana S., Cappai P., Superovulatory response and quality of embryos recovered from anestrus ewes after a single injection of porcine FSH dissolved in polyvinylpyrrolidone, Theriogenology 42 (1994) 235-239.
[31] De Matos D.G., Furnus C.C., Moses D.F., Baldassarre H., Effect of cysteamine on glutathione level and developmental capacity of bovine oocyte matured in vitro, Mol. Reprod. Dev. 42 (1995) 432-436.

[32] Dean W., Bowden L., Aitchinson A., Klose J., Moore T., Mesenes J.J., Reik W., Feil R., Altered imprinted gene methylation and expression in completely ES cell-derived mouse fetuses: association with aberrant phenotypes, Development 125 (1998) 2273-2282.

[33] Driancourt M.A., Follicular dynamics in sheep and cattle, Theriogenology 35 (1991) 55-78.

[34] Drion P.V., Remy B., McNamara M., Baril G., Cognie Y., Heyman Y., Leboeuf B., TheauClement M.C., Desuleux H., Ectors F.J., Ectors F., Beckers J.F., Side effects of multiple treatments with exogenous gonadotrophins in cattle, sheep and goat, 13th AETE Scientific Meeting, Lyon, 1997, p. 71.

[35] Earl C.R., Irvine B.J., Kelly J..M., Rowe J.P., Armstrong D.T., Ovarian stimulation protocols for oocyte collection and in vitro embryo production from 8 to 9 week old lambs, Theriogenology 43 (1995) 203 (abstr.).

[36] Eckery D.C., Moeller C.L., Nett T.M., Sawyer H.R., Recombinant bovine somatotropin does not improve superovulatory response in sheep, J. Anim. Sci. 72 (1994) 2425-2430.

[37] Edwards RF, Maturation in vitro of mouse, sheep, cow, pig, rhesus monkey, and human ovarian oocytes, Nature 208 (1965) 249-251.

[38] Galli C., Moor R.M., Gonadotrophin requirements for the in vitro maturation of sheep oocytes and their subsequent embryonic development, Theriogenology 35 (1991) 1083-1093.

[39] Galli C., Laurie S., Lazzari G., Moor R.M., Nuclear transplantation (by electrofusion) of cultured embryonic cells with MII cytoplasts in the sheep, Atti. SiSVet. XLV (1991) 299-303.

[40] Gandolfï F., Autocrine, paracrine, and environmental factors influencing embryonic development from zygote to blastocyst, Theriogenology 41 (1994) 95-100.

[41] Gandolfi F., Moor R.M., Stimulation of early embryonic development in the sheep by co-culture with oviduct epithelial cells, J. Reprod. Fert. 81 (1987) 23-28.

[42] Gandolfi F., Pocar P., Luciano A.M., Rieger D., Effect of EGF and IGF-1 during in vitro maturation of cattle oocytes on subsequent embryo development and metabolism, Theriogenology 45 (1996) 277.

[43] Gardner D.K., Lane M., Spitzer A., Batt A., Enhanced rates of cleavage and development for sheep zygotes cultured to the blastocyst stage in vitro in the absence of serum and somatic cells: amino acids, vitamins, and culturing embryos in groups stimulate development, Biol. Reprod. 50 (1994) 390-400. 
[44] Gatica R., Boland M.P., Crosby T.F., Gordon I. Micromanipulation of sheep morulae to produce monozygotic twins, Theriogenology 21 (1984) 550-560.

[45] Gordon I., Controlled Reproduction in Sheep and Goats, CAB International, Wallingford, 1997.

[46] Harper K.M., Brackett B.G., Bovine blastocyst development after in vitro maturation in a defined medium with epidermal growth factor and low concentrations of gonadotrophins, Biol. Reprod. 48 (1993) 409-416.

[47] Heyman Y., Cloning of domestic species, Anim. Reprod. Sci. 42 (1996) 427-426.

[48] Heyman Y., Cloning in cattle: from embryo splitting to somatic nuclear transfer, 14th AETE Scientific Meeting, Venise, 1998.

[49] Heyman Y., Vincent C., Garnier V., Cognié Y., Transfer of frozen-thawed embryos in sheep, Vet. Rec. 120 (1987) 83-85.

[50] Hunter G.L., Adams C.E., Rowson L.E.A., Interbreed ovum transfer in sheep, J. Agric. Sci. 46 (1955) 143-149.

[51] Jabbour H.N., Ryan J.P., Evans G., Maxwell W.M.C., Effects of season. GnRH administration and lupine supplementation on the ovarian and endocrine responses of Merino ewes treated with PMSG and p-FSH to induce superovulation, Reprod. Nutr. Dev. 3 (1991) 699-707.

[52] Johnson L.A., Welch G.R., Rens W., Dobrinsky J.R., Enhanced flow cytometric sorting of mammalian $X$ and $Y$ sperm: high speed sorting and orienting nozzle for artificial insemination, Theriogenology 48 (1998) 361

[53] Johnson R.T., Rao P.N., Mammalian cell fusion: studies on the regulation of DNA synthesis and mitosis, Nature 225 (1970) 159-164

[54] Kobayashi K., Yamashita S., Hoshi H., Influence of epidermal growth factor- $\alpha$ on in vitro maturation of cumulus cell-enclosed bovine oocytes in a defined medium, J. Reprod. Fert. 100 (1994) 439-446.

[55] Ledda S., Loi P., Fulka Jr. J., Moor R.M., The effect of 6-dimethylaminopurine on DNA synthesis in activated mammalian oocytes, Zygote 4 (1996) 7-9.

[56] Ledda S., Bogliolo L., Calvia P., Leoni G., Naitana S., Meiotic progression and developmental competence of oocytes collected from juvenile and adult ewes, J. Reprod. Fert. 109 (1997) 73-78.

[57] Loi P., Boyazoglu S., Ledda S., Naitana S., Cappai P., Wilmut I., Casu S., Embryo cloning in sheep: work in progress, Theriogenology 4 (1997) $1-10$.

[58] Loi P., Ledda S,, Fulka Jr J., Cappai P., Moor R.M., Development of parthenogenetic and cloned ovine embryos: effect of activation protocols, Biol. Reprod. 58 (1998) 1177-1187.

[59] Looney C.R., Bondioli K.R., Hill K.C., Massey J.M., Superovulation of donor cows with bovine follicle-stimulating hormone (bFSH) produced by recombinant DNA technology, Theriogenology 29 (1988) 271.
[60] Maxwell W.M.C., Szell A., Hunton J.R., Ryan J.P., Artificial breeding: embryo transfer and cloning, in: Oldham C.M., Martin C.B., Purvis I.W. (Eds.), Reproductive Physiology of Merino Sheep: Concept and Consequences, 1990, pp. 217-237.

[61] McEvoy T.G., Robinson J.J., Aitken R.P., Findlay P.A., Robertson I.S., Relationship between pre-ovulatory feed intake, progesterone priming and the subsequent in vitro development of ova collected from superovulated ewes, Theriogenology 43 (1995) 276.

[62] McKelvey W.A.C., Robinson J.J., Aitken R.P., A simplified technique for the transfer of ovine embryos by laparoscopy, Vet. Rec. 117 (1985) 492-494.

[63] McKelvey W.A.C., Robinson J.J., Aitken R.P., Repeated recoveries of embryos from ewes by laparoscopy, Theriogenology 25 (1986) 855-865.

[64] Meinecke-Tillman S., Lewalski H., Meinecke B., Induction of superovulation in Merinolandshaf ewes after single or multiple FSH injections, Reprod. Domest. Anim. 28 (1993) 433-440.

[65] Moor R.M., Osborn J.C., Somatic control of protein synthesis in mammalian oocytes during maturation, in: Whelan I. (Ed.), Molecular Biology of Egg Maturation, Pitman Books, London, 1983, pp. 179-196.

[66] Moor R.M., Kruip Th..A.M., Green D., Intraovarian control of folliculogenesis: limits to superovulation?, Theriogenology 21 (1984) 103-116.

[67] Moor R.M., Osborn J.C., Crosby I.M., Gonadotropin induced abnormalities in sheep oocytes after superovulation, J. Reprod. Fert. 74 (1985) 167-172.

[68] Moore N.W., Egg transfer in sheep and goat, in: Adams C.E. (Ed.), Mammalian Egg Transfer, CRC Press, Boca Raton, FL, 1982, pp. 119133.

[69] Moore N.W., Shelton J.N., The application of the technique of embryo transfer to sheep breeding, Aust. J. Agric. Res. 13 (1962) 718-724.

[70] Moore N.W., Shelton J.N., Oestrus an ovarian response of the ewe to a horse anterior pituitary extract, Nature 194 (1964) 1283-1284.

[71] Moses R.M., Masui Y., Enhancement of mouse egg activation by the kinase inhibitor, 6-dimethylaminopurine, 6-DMAP, J. Exp. Zool. 270 (1994) 211-218.

[72] Naitana S., Loi P., Ledda S., Cappai P., Embryo transfer and new technology in sheep reproduction, in: Lauria A., Gandolfi F. (Eds.), Embryonic Development and Manipulation in Animal Production: Trends in Research and Applications, Portland Press, London, 1992, pp. 183-194.

[73] Naitana S., Dattena M., Gallus M., Loi P., Branca A., Ledda S., Cappai P., Recipient synchronization affects viability of vitrified ovine blastocyst, Theriogenology 43 (1995) 13711378 . 
[74] Naitana S., Loi P., Ledda S., Cappai P., Dattena M., Bogliolo L., Leoni G., Effect of biopsy and vitrification on in vitro survival of ovine embryos at different stages of development, Theriogenology 46 (1996) 813-824.

[75] Naitana S., Ledda S., Loi P., Leoni G., Bogliolo L., Dattena M., Cappai P., Polyvinyl alcohol as a definite substitute for serum in vitrification and warming solutions to cryopreserve ovine embryos at different stages of development, Anim. Reprod. Sci. 48 (1997) 247-256.

[76] Nellenschulte E., Niemann H., Collection and transfer of ovine embryos by laparoscopy, Anim. Reprod. Sci. 27 (1992) 293-304.

[77] Nicholas F.W., Genetic improvement through reproductive technology, Anim. Reprod. Sci. 42 (1996) 205-214.

[78] Niemann H., Cryopreservation of ova and embryos from livestock: current status and research needs, Theriogenology 35 (1991) 109124.

[79] O'Brien J.K., Dwarte D., Ryan J.P., Maxwell W.M.C., Evans G., Developmental capacity, energy metabolism and ultrastructure of mature oocytes from prepubertal and adult sheep, Reprod. Fert. Dev. 8 (1996) 1029-1037.

[80] O'Brien J.K., Beck N.F.G., Maxwell W.M.C., Evans G., Effect of hormone pre-treatment of prepubertal sheep on the production and developmental capacity of oocytes in vitro and in vivo, Reprod. Fert. Dev. 9 (1997) 625-631.

[81] O'Brien J.K., Catt S.L., Ireland K.A., Maxwell W.M.C., Evans G., In vitro and in vivo developmental capacity of oocytes from prepubertal and adult sheep, Theriogenology 47 (1997) 1433-1443.

[82] Otaegui P.J., O’Neil J.T., Campbell K.H.S., Wilmut I., Transfer of nuclei from 8 cell stage mouse embryos following use of nocodazole to control the cell cycle, Mol. Reprod. Dev. 39 (1994) 147-152.

[83] Ptak G., Loi P., Dattena M., Cappai P., Tischner M., IVM/IVF techniques in prepubertal lamb oocytes, Proc 13th AETE Scientific Meeting, Lyon, 1997, p. 192.

[84] Ptak G., Dattena M., Loi L., Tischner M., Cappai P., Repeated oocytes recovery for IVP of ovine blastocysts, Proc. 50th ICAR, Milan, 1998, p. 591 .

[85] Pugh P.A., Fukui Y., Tervit H.R., Thompson J.G., Developmental ability of in vitro matured sheep oocytes collected during nonbreeding season and fertilized in vitro with frozen ram semen, Theriogenology 36 (1991) 771-778.

[86] Rall W.F., Cryopreservation of oocytes and embryos: methods and applications, Anim. Reprod. Sci. 28 (1992) 237-246.

[87] Rall W.F., Fahy G.M., Ice-free cryopreservation of mouse eggs at $-196^{\circ} \mathrm{C}$ by vitrification, Nature 313 (1985) 573-575.
[88] Rexroad C.E.J., Powel A.M., Co-culture of sheep ova and cells from sheep oviduct, Theriogenology 25 (1986) 187.

[89] Robinson J.J., Wallace J.M., Aitken R.P., Fertilization and ovum recovery rates following cervical insemination or laparoscopic intrauterine insemination at different times after progestagen withdrawal and in one or both uterine horns, J. Reprod. Fert. 87 (1989) 771-782.

[90] Robinson T.J., Synchronization of oestrus in sheep by intravaginal and subcutaneous application of progestin impregnated sponges, Proc. Australian Society Animal Production 8 (1964) 47-49.

[91] Ryan J.P., Hunton J.R., Maxwell W.M.C., Increased production of sheep embryos following superovulation of Merino ewe with a combination of pregnant mare serum gonadotrophin and follicle stimulating hormone, Reprod. Fert. Dev. 3 (1991) 551-560.

[92] Schieve M.C., Howard J.G., Goodrove K. Wildt D.E., Human menopausal gonadotrophin induces ovulation in sheep, but embryo recovery after prostaglandin $\mathrm{F} 2 \alpha$ synchronization is compromised by premature luteal regression, Theriogenology 34 (1990) 469-486.

[93] Schnieke A.E., Kind A.J., Ritchie W.A., Mycock K., Scott A.R., Ritchie M., Wilmut I., Colman A., Campbell K.H.S., Human factor IX transgenic sheep produced by transfer of nuclei from transfected fetal fibroblasts, Science 278 (1997) 2130-2133.

[94] Scudamore C.L., Robinson J.J., Aitken R.P., The effect of timing of laparoscopic insemination in superovulated ewes, with or without sedation, on the recovery of embryos, their stage of development and susequent viability, Theriogenology 35 (1991) 907-914.

[95] Scudamore C.L., Robinson J.J., Aitken R.P., Kennedy D.J., Ireland S., Robertson I.S., Laparoscopy for intrauterine insemination and embryo recovery in a commercial embryo transfer unit, Theriogenology 35 (1991) 329-337.

[96] Smith C.L., Dose effect of follicle stimulating hormone for superovulation of crossbreed Targhee ewes, Theriogenology 21 (1984) 262.

[97] Snyder D.A., Nellor J.E., Development of the laparoscopic technique for in vivo collection of follicular oocytes in sheep, Fed. Proc. 34 (1975) 338.

[98] Staigmiller R.B., Moor R.M., Effect of follicle cells on the maturation and developmental competence of ovine oocytes matured outside the follicle, Gamete Res. 9 (1984) 221-229.

[99] Szell A.Z., Windsor D.P., Survival of vitrified sheep embryos in vitro and in vivo, Theriogenology 42 (1994) 881-889.

[100] Tervit H.R., Laparoscopy/laparotomy oocyte recovery and juvenile breeding, Anim. Reprod. Sci. 42 (1996) 227-238. 
[101] Tervit H.R., Havik P.G., A modified technique for flushing ova from the sheep uterus, New Zeal. Vet. J. 24 (1976) 138-140.

[102] Tervit H. R., Goold P. G., Deep-freezing of sheep embryos, Theriogenology 21 (1984) 268.

[103] Tervit H.R., Whittingham D.G., Rowson L.E.A., Successful culture in vitro of sheep and cattle ova, J. Reprod. Fert. 30 (1972) 493-497.

[ 104] Tervit H.R, Smith J.F., McGowan L.T., Wells R.W., Pugh P.A., Laparoscopic recovery of ovarian oocytes from slaughtered or living sheep, Proc. Aust. Soc. Reprod. Biol. 25 (1993) 7.

[105] Tervit H.R., Smith J.F., McGowan L.T., Pugh P.A., Birth of lambs from embryos produced in vitro following laparoscopic recovery of follicular oocytes, Proc. Aust. Soc. Reprod. Biol. 27 (1995) 68.

[106] Thompson J.G., Comparison between in vivoderived and in vitro-produced pre-elongation embryos from domestic ruminants, Reprod. Fert. Develop. 9 (1997) 341-354.

[107] Thompson J.G., Gardner D.K., Pugh P.A., McMillan W.H., Tervit H.R., Lamb birth weight is affected by culture system utilized during in vitro pre-elongation development of ovine embryos, Biol Reprod 53 (1995) 1385-1391.

[108] Torres S., Sevellec C., Repeated superovulation and surgical recovery of embryos in the ewe, Reprod. Nutr. Dev. 27 (1987) 859-863.

[109] Trounson A.O., Moore N.W., Fertilization in the ewe following multiple ovulation and uterine insemination, Aust. J. Biol. Sci. 27 (1974) 505-510.

[110] Vivanco H.W., Rangel D.H., Lynch P., Rodhes A., Large scale commercial application of bisection of sheep embryos, Theriogenology 35 (1991) 292.

[111] Walker S.K., Smith D.H., Seamark R.F., Timing of multiple ovulation in the ewe after treat ent with FSH or PMSG with or without GnRH, J. Reprod. Fert. 77 (1986) 135-142.

[112] Walker S.K., Heard T.M., Seamark R.F., In vitro culture of sheep embryos without co-culture: successes and perspectives, Theriogenology 37 (1992) $111-126$.
[113] Walker S.K., Hartwich K.M., Seamark R.F., The production of unusually large offspring following embryo manipulation: concepts and challenges, Theriogenology 45 (1996) 111-120.

[114] Watson A.J., Watson P.H., Warnes D., Walker S.K., Armstrong D.T., Seamark R.F., Preimplantation development of in vitro-matured and in vitro-fertilized ovine zygotes: comparison between coculture on oviduct epithelial cell monolayers and culture under low oxygen atmospheres, Biol. Reprod. 50 (1994) 715-724.

[115] Wells D.N., Misica P.M., Day A.M., Tervit H.R., Production of cloned lambs from an established embryonic cell line: a comparison between in vivo and in vitro matured cytoplasts, Biol. Reprod. 57 (1997) 385-393.

[116] Willadsen S.M., A method for culture of micromanipulated sheep embryos and its use to produce monozygotic twins, Nature 277 (1979) 298-300.

[117] Willadsen S.M., The development capacity of blastomeres from 4- and 8-cell sheep embryos, J. Embryol. Exp. Morph. 65 (1981) 165-172.

[118] Willadsen S.M., Nuclear transplantation in sheep embryos, Nature 320 (1986) 63-65.

[119] Willadsen S.M., Godke R.A., A simple procedure for the production of identical sheep twins, Vet. Rec. 114 (1984) 240-243.

[120| Willadsen S.M., Polge C., Rowson L.E.A., Moor R.M., Deep freezing of sheep embryos, J. Reprod. Fert. 46 (1974) 151-154.

[121] Wilmut I., Clark A.J., Basic techniques for transgenesis, J. Reprod. Fertil. Suppl. 43 (1990) 265 275.

[122] Wilmut I., Schnieke A.E., McWhir J., Kind A.J., Campbell K.H.S., Viable offspring derived from fetal and adult mammalian cells, Nature 385 (1997) 810-813.

[123] Wright G., Carver A., Cottom D., Reeves D., Scott A., Simons P., Wilmut I., Garner I., Colman A., High-level expression of active human alpha-1-antitrypsin in the milk of transgenic sheep, Biol. Technol. 9 (1991) 830-834. 